\title{
Soft-shelled turtles (Trionychidae) from the Cenomanian of Uzbekistan
}

\author{
Natasha S. Vitek ${ }^{\mathrm{b}}$, Igor G. Danilov ${ }^{\mathrm{a}, *}$ \\ a Jackson School of Geosciences, The University of Texas at Austin, Austin, TX, USA \\ ${ }^{\mathrm{b}}$ Zoological Institute of the Russian Academy of Sciences, Universitetskaya Emb. 1, 199034 St. Petersburg, Russia
}

\section{A R T I C L E I N F O}

\section{Article history:}

Received 14 June 2013

Accepted in revised form 11 January 2014

Available online 22 February 2014

\section{Keywords:}

Turtles

Testudines

Trionychidae

Assemblage

Cretaceous

Middle Asia

Kazakhstan

\begin{abstract}
A B S T R A C T
Localities from the Cenomanian of Uzbekistan are the oldest in Middle Asia and Kazakhstan to preserve two broadly sympatric species of trionychid turtle. Material described here comes from multiple Cenomanian formations from the Itemir locality, and from multiple localities in the Cenomanian Khodzhakul Formation. The first taxon from the locality, "Trionyx" cf. kyrgyzensis, has multiple morphological similarities with the older, Early Cretaceous "Trionyx" kyrgyzensis. In contrast, the second taxon, "Trionyx" dissolutus, has multiple similarities with "Trionyx" kansaiensis, one of two species of trionychid found in younger Late Cretaceous localities. "Trionyx" dissolutus bears some superficial resemblance to other trionychid taxa within the clade Plastomenidae because of its highly ossified plastron with a hyoplastral lappet and an epiplastral notch. However, Plastomenidae is diagnosed primarily through characters that are absent or cannot be observed in the available material of "T." dissolutus, and other shared features are plesiomorphic. In addition, "T." dissolutus shares other synapomorphies with Trionychinae. A heavily ossified plastron may be more homoplastric within Trionychidae than has been previously recognized. Finally, we provide an improved understanding of the subtle similarities and differences between several closely related Cretaceous turtle assemblages of Middle Asia and Kazakhstan.
\end{abstract}

(c) 2014 Elsevier Ltd. All rights reserved.

\section{Introduction}

Trionychidae Gray 1825, or soft-shelled turtles, are a group of aquatic cryptodires (Meylan,1987). The phylogeny and taxonomy of extinct species within this group are still not well understood (Meylan, 1987; Gardner et al., 1995; Karl, 1998; Joyce and Lyson, 2011). The lack of understanding is especially problematic for Cretaceous trionychids, which are important for understanding the early diversification and evolution of the family (Danilov and Vitek, 2012 provided a review of Cretaceous trionychids of Asia).

This paper continues a series of publications on Cretaceous trionychids of Asia (Danilov and Vitek, 2009; Vitek and Danilov, 2010, 2012, 2013; Danilov and Vitek, 2012, 2013) and is devoted to trionychids from the early Late Cretaceous (Cenomanian) of Uzbekistan, situated in the region called Middle Asia and Kazakhstan (Fig. 1; see Vitek and Danilov [2010] for more details about the geography of Middle Asia and Kazakhstan). The material described in this paper comes from localities in the early Cenomanian Khodzhakul Formation of the southwestern Kizylkum Desert area,

\footnotetext{
* Corresponding author.

E-mail address: igordanilov72@gmail.com (I.G. Danilov).
}

Karakalpakistan, and from the Cenomanian of the Itemir locality in the central Kizylkum Desert, Navoi Viloyat (district) (Fig. 1). The localities of the Khodzhakul Formation include Chelpyk (SCH-1 and SCH-“B” sites), Khodzhakul I (SKH-20 site), Khodzhakulsai (SKH-4, SKH-5, and SKH-25 sites), and Sheikhdzheili (SSHD-8 and SSHD-8a sites) (see Averianov and Archibald [2005] for more details about the localities of the Khodzhakul Formation). In addition, one more locality known as Khodzhakul II (SKH-26 site) contains Cenomanian remains from the Khodzhakul Formation which were redeposited in Late Paleocene sands (Nessov, 1997). The described material from Itemir comes from several Cenomanian members (formations) of the following sites: CDZH-3, CDZH-5b, CDZH-10, CDZH-12 and IT-1 (see Nessov (1997) and Averianov and Sues (2007) for more details about the Itemir locality).

Trionychid material from the Khodzhakul Formation was mentioned in the literature (Nessov, 1977a, 1985, 1986; Kordikova, 1992, 1994; Nessov, 1997), but was never described. The trionychid material from the Itemir locality was mentioned and partially illustrated (Nessov, 1984, 1985; Kordikova, 1992, 1994; Nessov, 1997; Danilov and Vitek, 2009, 2012).

The trionychid material described in this paper consists of numerous shell fragments. It is assigned to two shell-based taxa, "Trionyx" cf. kyrgyzensis Nessov, 1995 and "Trionyx" dissolutus sp. 


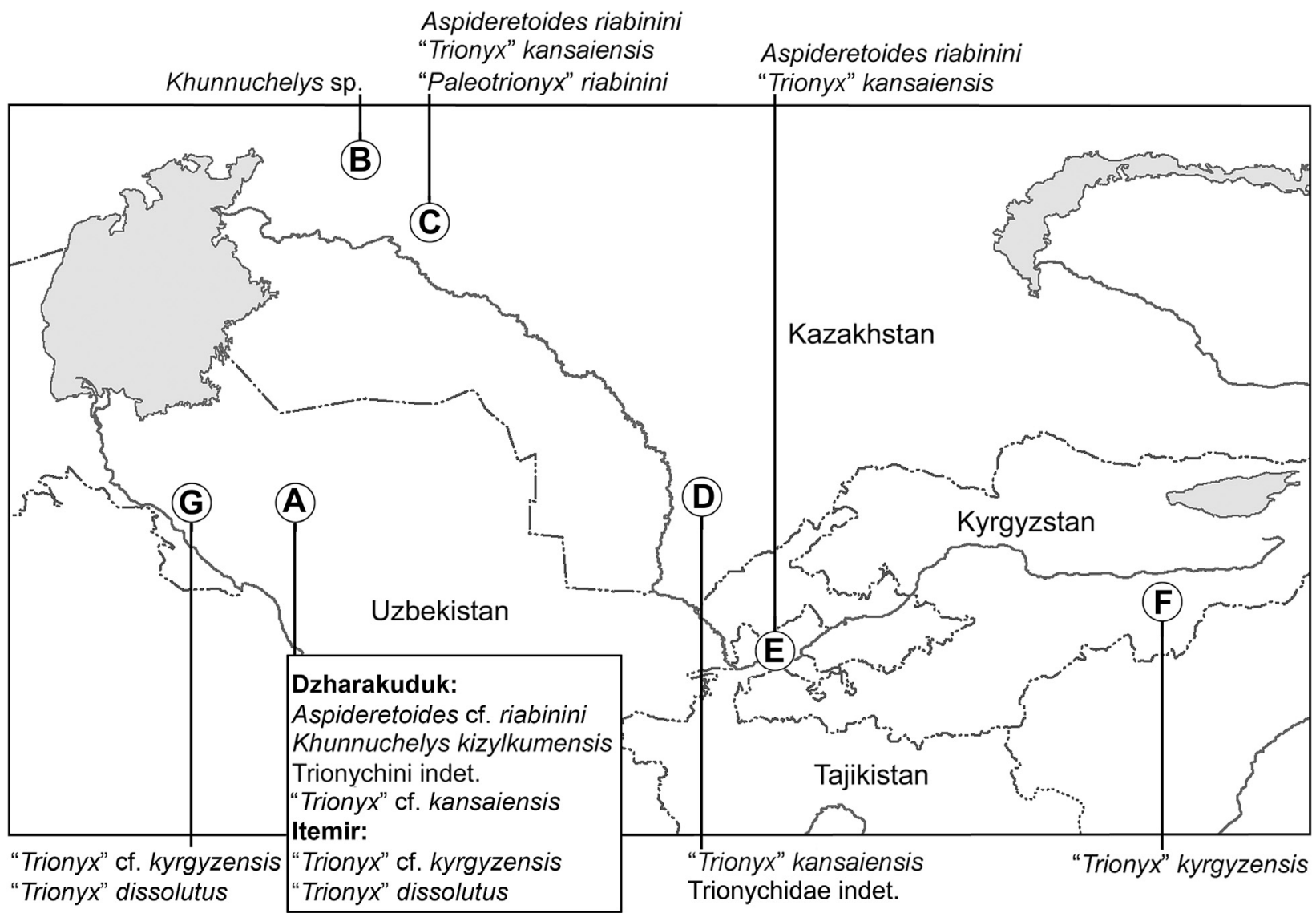

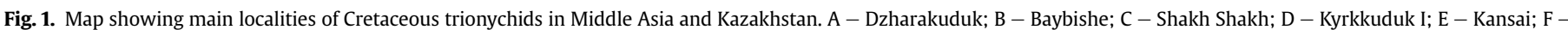

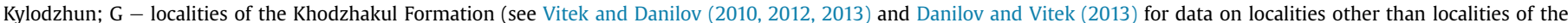
Khodzhakul Formation and Itemir).

nov. Material that cannot be confidently attributed to these two taxa is considered Trionychidae indet.

The material for this study was collected by L.A. Nessov between 1977 and 1994 and by the international Uzbek/Russian/British/ American/Canadian Joint Paleontological Expeditions (URBAC) led by J.D. Archibald between 1997 and 2006.

Anatomical terminology follows Meylan (1987), Gardner and Russell (1994), and Karl (1999).

Institutional Abbreviations - ZIN PH, Paleoherpetological collection, Zoological Institute of the Russian Academy of Sciences, St. Petersburg, Russia.

\section{Systematic paleontology}

Testudines Batsch, 1788

Cryptodira Cope, 1868

Trionychidae Gray, 1825

Trionychinae Gray, 1825

Trionychinae incertae sedis

“Trionyx" cf. kyrgyzensis Nessov, 1995

Referred material. Khodzhakul Formation: ZIN PH 1/122 (SSHD-8a), ZIN PH 2/122 (SKH-4), ZIN PH 3/122 (SKH-26), ZIN PH 27/122 (SSHD-8a), ZIN PH 30/122 (SKH-20), partial nuchals; ZIN PH 15/122 (SSHD-8), hexagonal neural; ZIN PH 69/122 (SSHD-8), tetragonal neural; ZIN PH 14/122 (SKH-20), pentagonal neural; ZIN PH 6/122 (SSHD-8), partial costal 1; ZIN PH 7/122 (SSHD-8a), partial costal 2?; ZIN PH 37/122 (SSHD-8a), partial costal 5; ZIN PH 9/122 (SSHD- 8a), partial costal 7?; ZIN PH 5/122 (SSHD-8), partial costal 8; ZIN PH 11/122 (SKH-4), partial costal 8?; ZIN PH 10/122 (SSHD-8a), partial costal; ZIN PH 16/122 (SKH-25), ZIN PH 17/122 (SKH-25), ZIN PH 23/122 (SKH-25), ZIN PH 24/122 (SKH-25), partial hyoplastra; ZIN PH 18/122 (SSHD-8a), ZIN PH 20/122 (SKH-25), ZIN PH 21/122 (SKH-25), ZIN PH 22/122 (SKH-25), partial hypoplastra; ZIN PH 58/122 (SKH-25), ZIN PH 59/122 (SCH-1), partial xiphiplastra; Itemir locality: ZIN PH 56/86 (CDZH-5b), partial nuchal; ZIN PH 57/86 (IT-1), costal 8; ZIN PH 54/86 (CDZH-12), ZIN PH $55 / 86$ (CDZH-12), external impressions of partial costals 7 and 8.

Locality, Horizon, and Age. Chelpyk, Khodzhakul I and II, Khodzhakulsai, and Sheikhdzheili localities, southwestern Kizylkum Desert area, Karakalpakistan, Uzbekistan; Khodzhakul Formation, early Cenomanian. Itemir locality, Central Kizylkum Desert, Navoi Viloyat (district), Uzbekistan; Cenomanian.

Description of material from the Khodzhakul Formation. Shell. A reconstruction (Fig. 2A), based on the largest nuchal fragment (ZIN PH 2/122; Fig. 3A), is approximately $30 \mathrm{~cm}$ long. A smaller partial nuchal (ZIN PH 3/122; Fig. 3B) with a callosity restricted to the posteromedial part of the bone comes from an individual, likely a juvenile, only about $15 \mathrm{~cm}$ long (Fig. 2B). Carapace shape was probably oval, but without complete costals $2-7$ it is impossible to say for certain. It is possible that the carapace was more circular. The anterior and posterior margins are both broadly convex, following the terminology of Gardner and Russell (1994). The lateral margin is weakly scalloped. It is unclear whether or not this species was sexually dimorphic. Sculpturing 

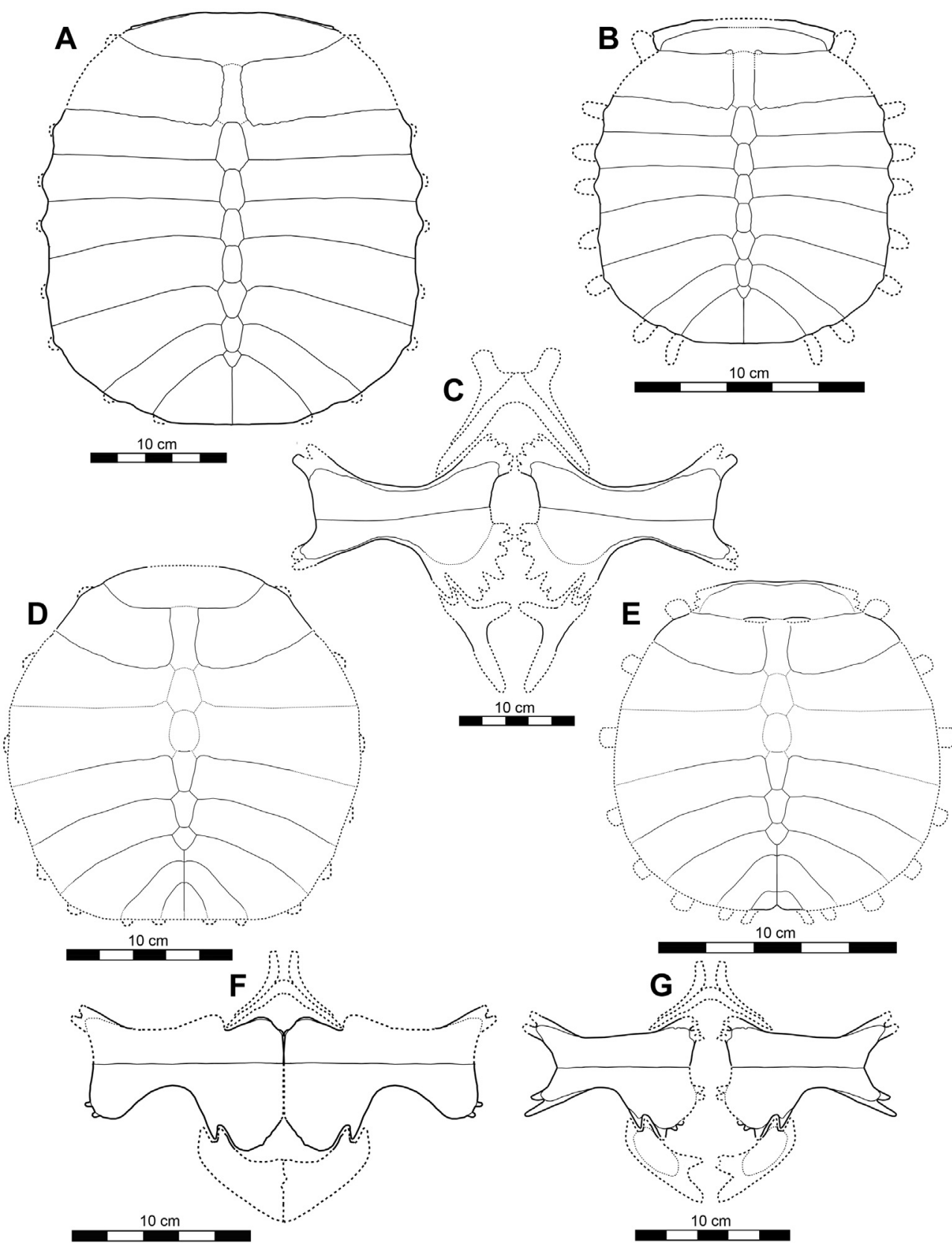

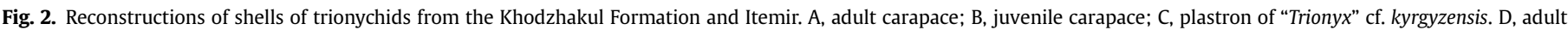
carapace; E, juvenile carapace; F, adult plastron; G, juvenile plastron of "Trionyx" dissolutus sp. nov.

is a pattern of wide, irregularly shaped pits. In smaller specimens, the ridges surrounding the pits are thinner and more pronounced, similar to the sculpturing seen in "T." kyrgyzensis Nessov, 1995. In general, this sculpturing is more similar to that of Aspideretoides riabinini (Kuznetsov and Chkhikvadze, 1987), than to that of "Trionyx" kansaiensis Vitek and Danilov, 2010 (see Vitek and Danilov, 2010; Danilov et al., in press).

Nuchal. Available nuchal fragments do not preserve the medial part of the nuchal. Therefore, it is unknown where the first thoracic vertebra contacted the nuchal. The costiform processes are united, in contrast to the divided processes of cyclanorbines. A rough estimate based on two different nuchals (ZIN PH 1/122 and ZIN PH 3/122) is that the nuchals were 4.5-5 times wider than long, similar to all Asian Cretaceous trionychids with preserved nuchals (Danilov and Vitek, 2012), but contrary to the hypothesized ancestral state for trionychids (Meylan, 1987). The extent of the sculptured callosity across the plate varies with size. Smaller nuchals (ZIN PH 3/122, ZIN PH 27/122; Fig. 3C) have a smaller callosified area than larger nuchals (ZIN PH 1/122; Fig. 3D), which in turn have a smaller callosified area than the largest nuchals (ZIN PH 2/122). In general, the nuchals are wellsutured to the first costals (ZIN PH 1/122) with a relatively straight suture between the two plates. A few millimeters of the posterior margin may lie inside the first costals. Only one small, presumably juvenile specimen (ZIN PH 30/122; Fig. 3E) has postnuchal fontanelles.

Neurals. No preneurals or neurals 1 could be assigned to this species. The medial margin of costal 1 (ZIN PH 6/122; Fig. 3F) does 


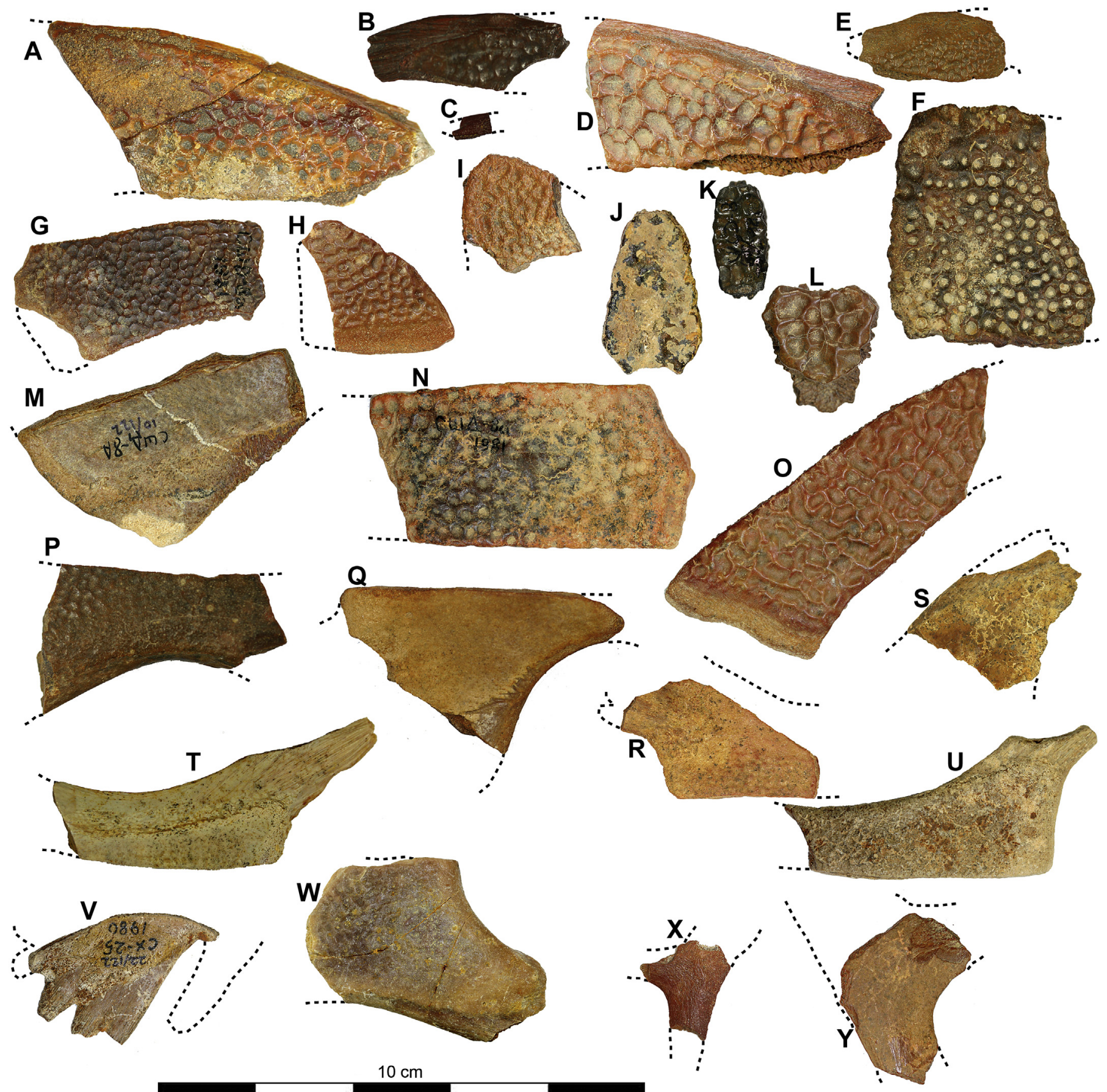

Fig. 3. "Trionyx" cf. kyrgyzensis specimens from the Khodzhakul Formation. A, ZIN PH 2/122, partial nuchal in external view; B, ZIN PH 3/122, partial nuchal in external view; C, ZIN PH 27/122, partial nuchal in external view; D, ZIN PH 1/122, partial nuchal in external view; E, ZIN PH 30/122, partial nuchal in external view; F, ZIN PH 6/122, partial costal 1 in external view; G, ZIN PH 37/122, partial costal 5 in external view; H, ZIN PH 5/122, partial costal 8 in external view; I, ZIN PH 11/122, partial costal 8? in external view; J, ZIN PH 15/ 122, hexagonal neural in external view; K, ZIN PH 69/122, tetragonal neural in external view; L, ZIN PH 14/122, pentagonal neural in external view; M, ZIN PH 10/122, partial costal in visceral view; N, ZIN PH 7/122, partial costal 2? in external view; O, ZIN PH 9/122, partial costal 7? in external view; P, ZIN PH 18/122, partial hypoplastron in external view; Q, ZIN PH 20/122, partial hypoplastron in external view; R, ZIN PH 16/122, partial hyoplastron in external view; S, ZIN PH 17/122, partial hyoplastron in external view; T, ZIN PH 23/122, partial hyoplastron in external view; U, ZIN PH 24/122, partial hyoplastron in external view; V, ZIN PH 22/122, partial hypoplastron in external view; W, ZIN PH 21/122, partial hypoplastron in external view; X, ZIN PH 59/122, partial xiphiplastron in external view; Y, ZIN PH 58/122, partial xiphiplastron in external view.

not indicate the presence of a preneural, but this does not necessarily mean that a preneural was absent. A mostly complete costal 5 (ZIN PH 37/122; Fig. 3G) indicates that neural 5 was tetragonal. The anteriomedial margin of costal 8 (ZIN PH 5/122, ZIN PH 11/122; Fig. $3 \mathrm{H}, \mathrm{I})$ indicates that the final neural was positioned between costals 7 and 8 . Therefore, it is most likely that this species had eight neurals. Neurals $1-4$ were hexagonal short-sided posteriorly
(ZIN PH 15/122; Fig. 3J), neural 5 was tetragonal (ZIN PH 69/122; Fig. 3K), neurals 6 and 7 were hexagonal short-sided anteriorly, and neural 8 was reduced and pentagonal (ZIN PH 14/122; Fig. 3L).

Costals. Eight costals are present, with costal 8 triangular, unreduced, and approximately as long as it is wide (ZIN PH 5/122). Costals 8 meet partially at the midline. Costals 7 and 8 make up the posterior margin of the carapace. There is no depression on costal 8 
for contact with the ilium. Most sutures between costals are straight, with no over- or underlap. The exception is a posterior fragment of what is probably costal 6 (ZIN PH 10/122; Fig. 3M). The anterior margin of costal 7 grew past the suture and underlapped this costal. All of the costal rib ends are broken off at the costal margin (ZIN PH 7/122, ZIN PH 9/122; Fig. 3N, O), making it impossible to tell how long the free rib ends were.

Plastron. No epiplastra or entoplastra could be identified among the material from the Khodzhakul Formation. The hyo- and hypoplastra are covered in a callosity, but the callosity is either weakly sculptured (e.g. ZIN PH 18/122, Fig. 3P) or lacks sculpturing (e.g. ZIN PH 20/122; Fig. 3Q). The xiphiplastra lack callosities entirely.

Hyoplastra and hypoplastra. The hyoplastra and hypoplastra are not fused together. There is no extensive midline contact between the hyoplastra and hypoplastra. The length of the plastral bridge is approximately one-quarter the width of the hypoplastron (Fig. 2C).

The medial lobe of the hyoplastron consists of several small processes that are left exposed and not entirely covered by a callosity (ZIN PH 16/122, ZIN PH 17/122; Fig. 3R, S). The two lateral hyoplastral processes are similarly left exposed (ZIN PH 23/122, ZIN PH 24/122; Fig. 3T, U). While both lobes extend anteriorly past the bridge, neither is significantly longer than the other.

The medial lobe of the hypoplastron is not entirely preserved, but a fragment (ZIN PH 22/122; Fig. 3V) indicates that the medial hypoplastral processes were numerous and undivided (clustered). The lateral lobe of the hypoplastron (ZIN PH 21/122; Fig. 3W) extends laterally past the suture between the hyoplastron and hypoplastron.

Xiphiplastra. Two central fragments of xiphiplastra are preserved (ZIN PH 58/122, ZIN PH 59/122; Fig. 3X, Y). Both indicate a long, thin posterior process.

Description of material from Itemir. Sculpturing of the carapace material from Itemir matches the sculpturing of the material from the Khodzhakul Formation. A partial nuchal (ZIN PH 56/86; Fig. 4A) is entirely covered by a callosity except for anterior-most edge, which is exposed, and the posterior margin, which lay inside the first costal. The costal 8 (ZIN PH 57/86; Fig. 4B) is triangular, with a space at the anteromedial margin for neural 8. Two impressions of costals 7 and 8 (ZIN PH 54/86, ZIN PH 55/86; Fig. 4C, D) show similar features.

\section{Trionychinae incertae sedis}

“Trionyx" dissolutus sp. nov.

Trionychidae indet.: Nessov, 1984:figs. 6, 7, 9; 1997:137, pl. 34, fig. 17; pl. 35, fig. 7; Kordikova, 1994:344.

Trionyx sp.: Nessov, 1985:216.

Trionyx s. lato: Kordikova, 1992:133.
Trionychinae indet.: Nessov, 1997:137.

Trionychini indet.: Danilov and Vitek, 2009:55.

Trionychini indet. 1: Danilov and Vitek, 2012:425.

Etymology. The species name dissolutus (Latin) means dissolved, and is used for the shell material that dissolved away and left impressions at the Itemir locality.

Holotype. ZIN PH 51/86 (formerly CCMGE 7/11659; CDZH-12), external and visceral impressions of posterior part of carapace of one individual.

Referred material. Itemir locality: ZIN PH 58/86 (CDZH-10), partial nuchal; ZIN PH 50/86 (CDZH-3), partial hyoplastron; ZIN PH 52/86 (CDZH-12), external impression of partial hyoplastron and hypoplastron; ZIN PH 59/86 (CDZH-10), partial xiphiplastron. Khodzhakul Formation: ZIN PH 32/122 (SSHD-8a), partial nuchal and costal 1; ZIN PH 25/122 (SKH-20), ZIN PH 29/122 (SSHD-8a), partial nuchals; ZIN PH 33/122 (SKH-25), ZIN PH 34/122 (SSHD-8), partial costals 1; ZIN PH 39/122 (SSHD-8a), partial costal 6; ZIN PH 42/122 (SSHD-8), 43/122 (SSHD-8a), costal 8; ZIN PH 44/122 (?), hexagonal neural; ZIN PH 46/122 (SKH-5), ZIN PH 50/122 (SSHD-8a), ZIN PH 54/122 (?), partial hyoplastra; ZIN PH 47/122 (SKH-5), ZIN PH 48/ 122 (SKH-26), ZIN PH 49/122 (SSHD-8a), ZIN PH 51/122 (SKH-25), ZIN PH 52/122 (SKH-25), ZIN PH 53/122 (SSHD-8), ZIN PH 57/122 (SKH-20), partial hypoplastra; ZIN PH 55/122 (SSHD-8a), partial xiphiplastron.

Locality, Horizon, and Age. Itemir locality, Central Kizylkum Desert, Navoi Viloyat (district), Uzbekistan; Cenomanian. Khodzhakul I and II, Khodzhakulsai, and Sheikhdzheili localities, southwestern Kizylkum Desert area, Karakalpakistan, Uzbekistan; Khodzhakul Formation, early Cenomanian.

Diagnosis. A trionychid with a shell length about $24 \mathrm{~cm}$, which can be differentiated from all other Cretaceous trionychids with known shells by the presence of six neurals and neural reversal anterior to neural 4. In addition, it can be differentiated from all Cretaceous trionychids, except for members of the clade Plastomenidae Hay, 1902, by the presence of an epiplastral notch on the hyoplastron. In addition it can be differentiated from all Cretaceous trionychids, except for Hutchemys spp., by extensive medial contact between the hyo- and hypoplastra. In addition, it can be differentiated from Axestemys spp. by its smaller size and two lateral hyoplastral processes; from Gilmoremys lancensis (Gilmore, 1928) by its smaller size and small costals 8; from "Trionyx" kansaiensis by its smaller

A
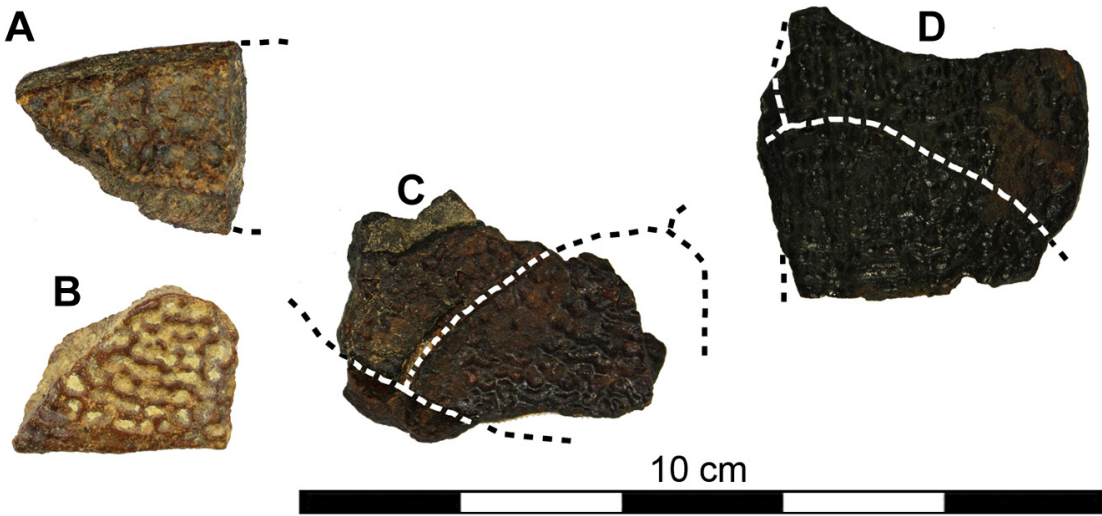

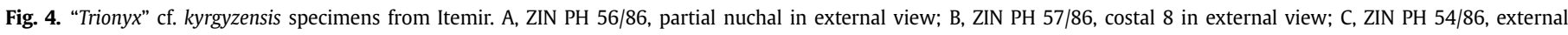
impression of partial costals 7 and 8; D, ZIN PH 55/86, external impression of partial costals 7 and 8. 
size, weak or absent nuchal emargination, small costals 8 and divided medial hypoplastral processes; from "Trionyx" gobiensis Danilov et al., in press and "T." kyrgyzensis by its small costals 8 , and divided medial hypoplastral processes. See Table 1 for further differences between "Trionyx" dissolutus and other Cretaceous trionychids.

Description of the holotype. Impressions of a posterior half of a carapace (ZIN PH 51/86; Fig. 5) preserve costals 4-8 and neurals 46. Sculpturing of the specimen is unclear. Both costals 7 and 8 are relatively small compared to the other costals. Neurals 4 and 5 are both hexagonal and short-sided anteriorly. Neural 6 is reduced, pentagonal, and lies between the pairs of costals 5 and 6 . This arrangement indicates that neural reversal occurred prior to neural 4. A reconstruction of the rest of the carapace, based on other material from both Itemir and the Khodzhakul Formation, is approximately $24 \mathrm{~cm}$ long (Fig. 2D; see more about reconstruction below).

Description of other material from Itemir. Sculpturing is identical to the type seen in the material from the Khodzhakul Formation (see below). A partial nuchal (ZIN PH 58/86; Fig. 6A, B) preserves a depression for the contact with the first thoracic vertebra at either the center or anterior of the nuchal. The nuchal emargination is weak.

A partial medial hyoplastron (ZIN PH 50/86; Fig. 6C, D) shows the beginnings of a hyoplastral shoulder or an anterior flap and epiplastral notch like the kind seen in Plastomenidae (Joyce et al., 2009; Hutchison, 2009; Joyce and Lyson, 2011). The medial processes are still uncovered by the callosity in this specimen. The callosity extends medially past the processes, but there is no suture at the medial margin to indicate that the hyoplastra were sutured at the midline. A partial impression of the hyo- and hypoplastral bridge (ZIN PH 52/86; Fig. 6E) shows that the angle between the medial and lateral lobes is wide. A fragment of a xiphiplastron (ZIN PH 59/86; Fig. 6F, G) is preserved with a callosity and sculpturing identical to other elements from this species.

Description of material from the Khodzhakul Formation. Shell. A reconstruction (Fig. 2D) with a size estimate based on an articulated partial nuchal and costal 1 (ZIN PH 32/122; Fig. 7A, B) is approximately $17 \mathrm{~cm}$ long. A more tentative estimate, based on an isolated hexagonal neural (ZIN PH 44/122; Fig. 7C), is about $22 \mathrm{~cm}$ long. Given evidence from Itemir (discussed above), this species may have been even larger, about $24 \mathrm{~cm}$ long. A reconstruction of a more juvenile specimen, scaled based on a partial nuchal (ZIN PH 25/122; Fig. 7D) with a large uncallosified anteromedial margin is approximately $13 \mathrm{~cm}$ long (Fig. 2E). Whether or not this species was sexually dimorphic is unclear. A lack of complete costals 1-7 makes estimation of the carapace shape impossible. The shape given in the reconstruction is tentative. Sculpturing is composed of rounded ridges more closely spaced than those in "Trionyx" cf. kyrgyzensis and more often forms a pattern of furrows rather than pits. This pattern gives an overall impression of much finer sculpturing than that seen in "T." cf. kyrgyzensis. In general, this pattern is similar to those of "Trionyx" kansaiensis (see Vitek and Danilov, 2010).

Nuchal. Reconstruction based on two different nuchals (ZIN PH 32/122, ZIN PH 29/122) show that the nuchal is approximately four times wider than long, similar to all Cretaceous Asian trionychids with a preserved nuchal (Danilov and Vitek, 2012). The nuchal emargination is weak. The costiform processes (sensu Meylan, 1987) are united (ZIN PH 29/122). The extent of sculpturing on the plate varies widely and correlates with size. Smaller trionychids (ZIN PH 25/122, ZIN PH 29/122; Fig. 7D-F) are not fully covered in a callosity, whereas larger specimens (ZIN PH 32/122) are entirely covered. A few millimeters of the posterior edge of the nuchal underlie the anterior edge of costal 1 (ZIN PH 33/122; Fig. 7G). Postnuchal fontanelles are present in smaller specimens (ZIN PH 25/122; Fig. 7D).

Neurals. The medial margin of costal 1 (ZIN PH 34/122; Fig. 7H) does not indicate the presence of a preneural, but neither does it definitely mean that a preneural was absent. No preneurals or neurals 1 were found that could give an indication whether or not a preneural was present. A hexagonal neural (ZIN PH 44/122; Fig. 7C) belongs to this species but which neural it is in the series and how many neurals there were in total is unknown.

Costals. An incomplete costal 6 (ZIN PH 39/122; Fig. 7K) is relatively large. Its lateral margin indicates that it made up part of the posterior margin of the carapace. This arrangement indicates that costals 7 and 8 were probably small relative to the other costals. Two costals 8 are preserved. The first one (ZIN PH 43/122; Fig. 7I) is reduced and eye-shaped. Another costal 8 (ZIN

Table 1

Comparison of shell characters of some species of Cretaceous trionychids. For data on species other than "Trionyx" dissolutus see Danilov et al. (in press).

\begin{tabular}{|c|c|c|c|c|c|c|c|c|c|c|}
\hline Characters & $\begin{array}{l}\text { "Aspideretes" } \\
\text { maortuensis }\end{array}$ & $\begin{array}{l}\text { Aspideretoides } \\
\text { riabinini }\end{array}$ & $\begin{array}{l}\text { Gilmoremys } \\
\text { lancensis }\end{array}$ & $\begin{array}{l}\text { Gobiapalone } \\
\text { breviplastra }\end{array}$ & $\begin{array}{l}\text { Gobiapalone } \\
\text { orlovi }\end{array}$ & $\begin{array}{l}\text { "Trionyx" } \\
\text { dissolutus }\end{array}$ & $\begin{array}{l}\text { "Trionyx" } \\
\text { gobiensis }\end{array}$ & $\begin{array}{l}\text { "Trionyx" } \\
\text { kansaiensis }\end{array}$ & $\begin{array}{l}\text { "Trionyx" } \\
\text { kyrgyzensis }\end{array}$ & $\begin{array}{l}\text { "Trionyx" } \\
\text { shiluutulensis }\end{array}$ \\
\hline Maximum carapace length, mm & $300^{*}$ & $500^{*}$ & 340 & $260 *$ & 335 & $240^{*}$ & $130^{*}$ & $750 *$ & $150^{*}$ & 225 \\
\hline Nuchal emargination & $?$ & Weak & Absent & $\begin{array}{l}\text { Weak } \\
\text { or absent }\end{array}$ & $\begin{array}{l}\text { Weak } \\
\text { or absent }\end{array}$ & Weak & $\begin{array}{l}\text { Weak } \\
\text { or absent }\end{array}$ & Strong & Absent & Weak \\
\hline Preneural & ? & Present & Present & Absent & Absent & $?$ & Absent & Absent & $?$ & Present \\
\hline Number of neurals & 8 & 7 & 7 & 7 or 8 or 9 & 7 or 8 & 6 & 7 or 8 & 7 or 8 & 8 & 8 \\
\hline Neural reversal & 5 & 5 or 6 & 6 & 5 & 5 & Prior to 4 & 5 & 5 & 5 & 6 \\
\hline Costals 8 & Small & Small & Large & $\begin{array}{l}\text { Small } \\
\text { or absent }\end{array}$ & Small & Small & Large & Large & Large & Small \\
\hline Epiplastral notch on hyoplastron & Absent & Absent & Present & Absent & Absent & Present & $?$ & Absent & Absent & $?$ \\
\hline Medial processes of hyoplastron & Present & Present & Absent & Present & Present & Absent & $?$ & Present & Present & $?$ \\
\hline $\begin{array}{l}\text { Lateral hyoplastron lobe in } \\
\text { relation to medial hyoplastron } \\
\text { lobe }\end{array}$ & $?$ & Shorter & $\begin{array}{l}\text { Almost } \\
\text { equal }\end{array}$ & Shorter & Shorter & $?$ & $?$ & Longer & Longer & $?$ \\
\hline $\begin{array}{l}\text { Ratio of minimal bridge length } \\
\text { to maximal hypoplastron } \\
\text { length }\end{array}$ & $?$ & About $50 \%$ & About $100 \%$ & About $50 \%$ & About $50 \%$ & $?$ & $?$ & $50-60 \%$ & About $50 \%$ & $?$ \\
\hline $\begin{array}{l}\text { Extensive medial contact of } \\
\text { hyo- and hypoplastra }\end{array}$ & No & No & No & No & No & Yes & $?$ & No & No & $?$ \\
\hline Medial hypoplastral processes & Clustered & Divided & $?$ & Divided & Divided & Divided & $?$ & Clustered & Clustered & $?$ \\
\hline $\begin{array}{l}\text { Number of sculptured plastral } \\
\text { callosities }\end{array}$ & At least 2 & At least 4 & At least 4 & 5 & 5 & At least 4 & $?$ & At least 2 & Absent & $?$ \\
\hline
\end{tabular}




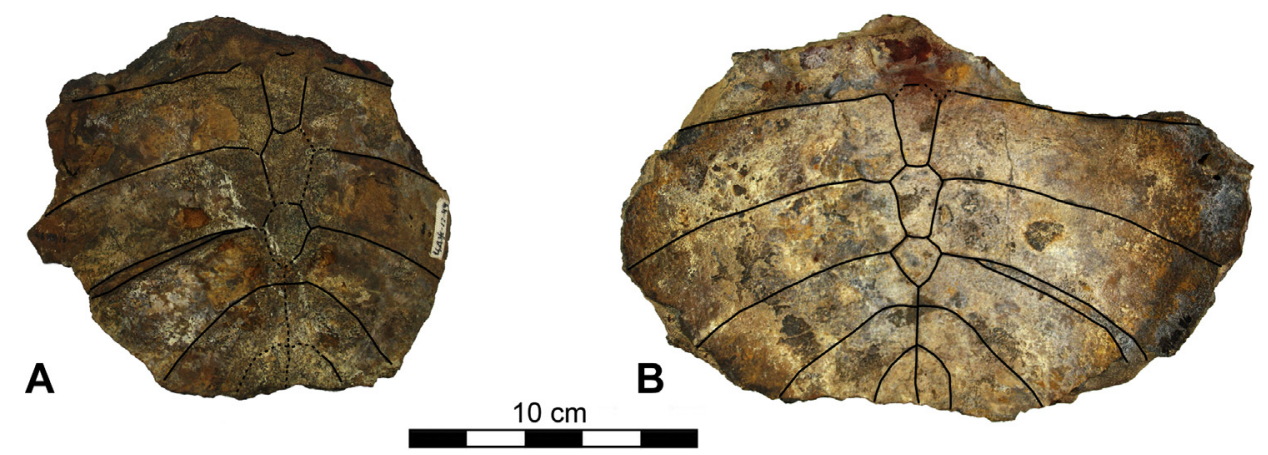

Fig. 5. "Trionyx" dissolutus sp. nov. holotype specimen from Itemir (ZIN PH 51/86). A, visceral impression of posterior part of carapace; B, external impression of the same.

PH 42/122; Fig. 7J) is similarly reduced, but longer anteroposteriorly and more triangular. The full costal was probably at least as long as it was wide, if not longer. There is no depression for contact with the ilium. The callosity on one lateral costal 1 fragment (ZIN PH 33/122) and on the fragment of costal 6 (ZIN $\mathrm{PH} 39 / 122$ ) has grown to cover the entire rib. Otherwise, ribs are broken off at the edge of costals, and the length of the free ends of the ribs are unknown.

Plastron. No epiplastra or entoplastra among the material from the Khodzhakul Formation could be assigned to this species. The hyoplastra, hypoplastra and xiphiplastra are covered in callosities with a sculpture pattern similar to the pattern on the carapace.

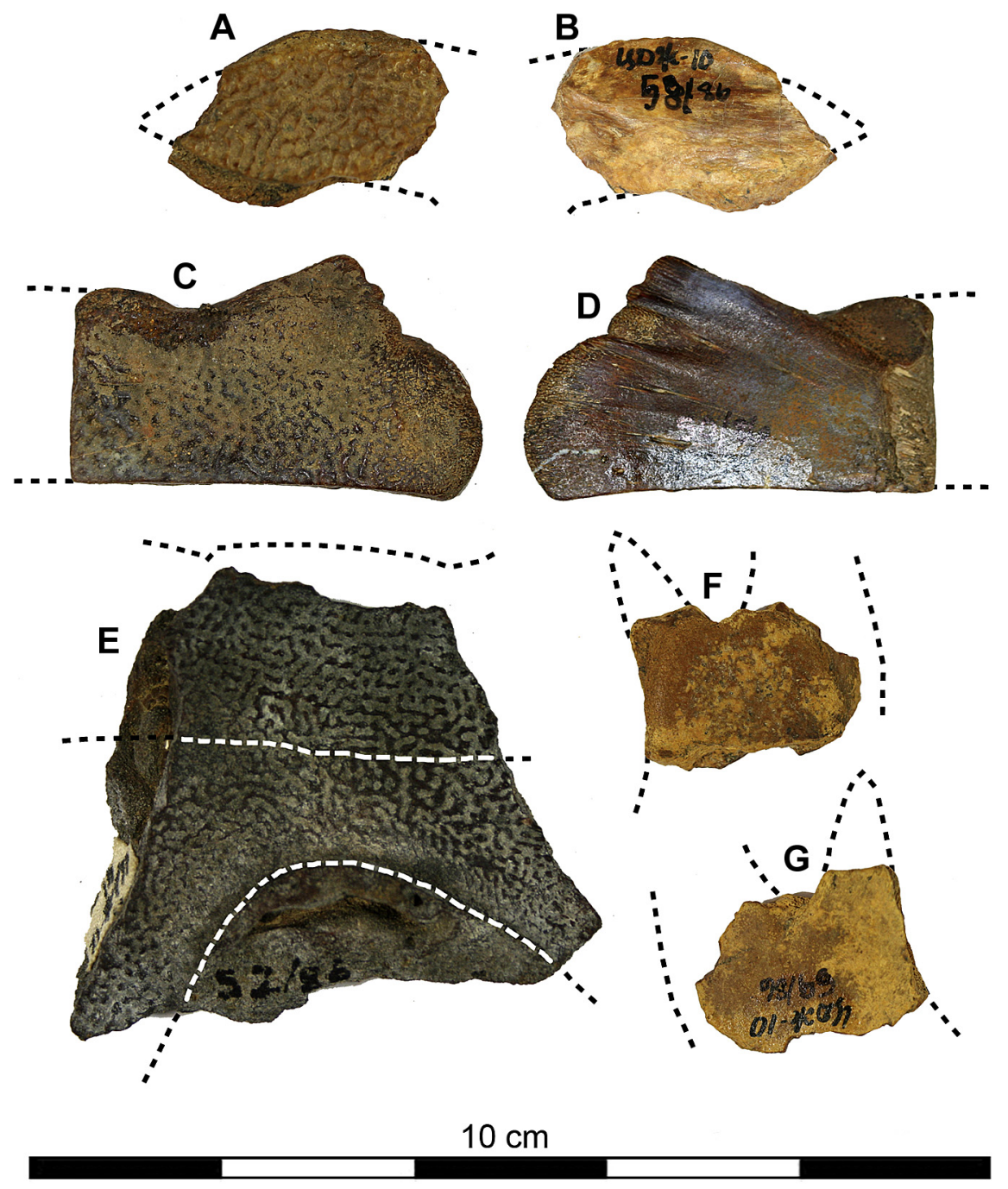

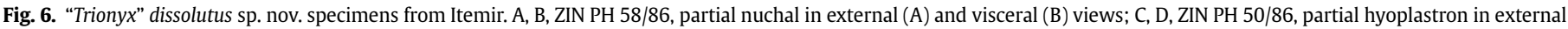

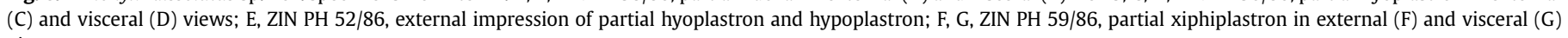
views. 


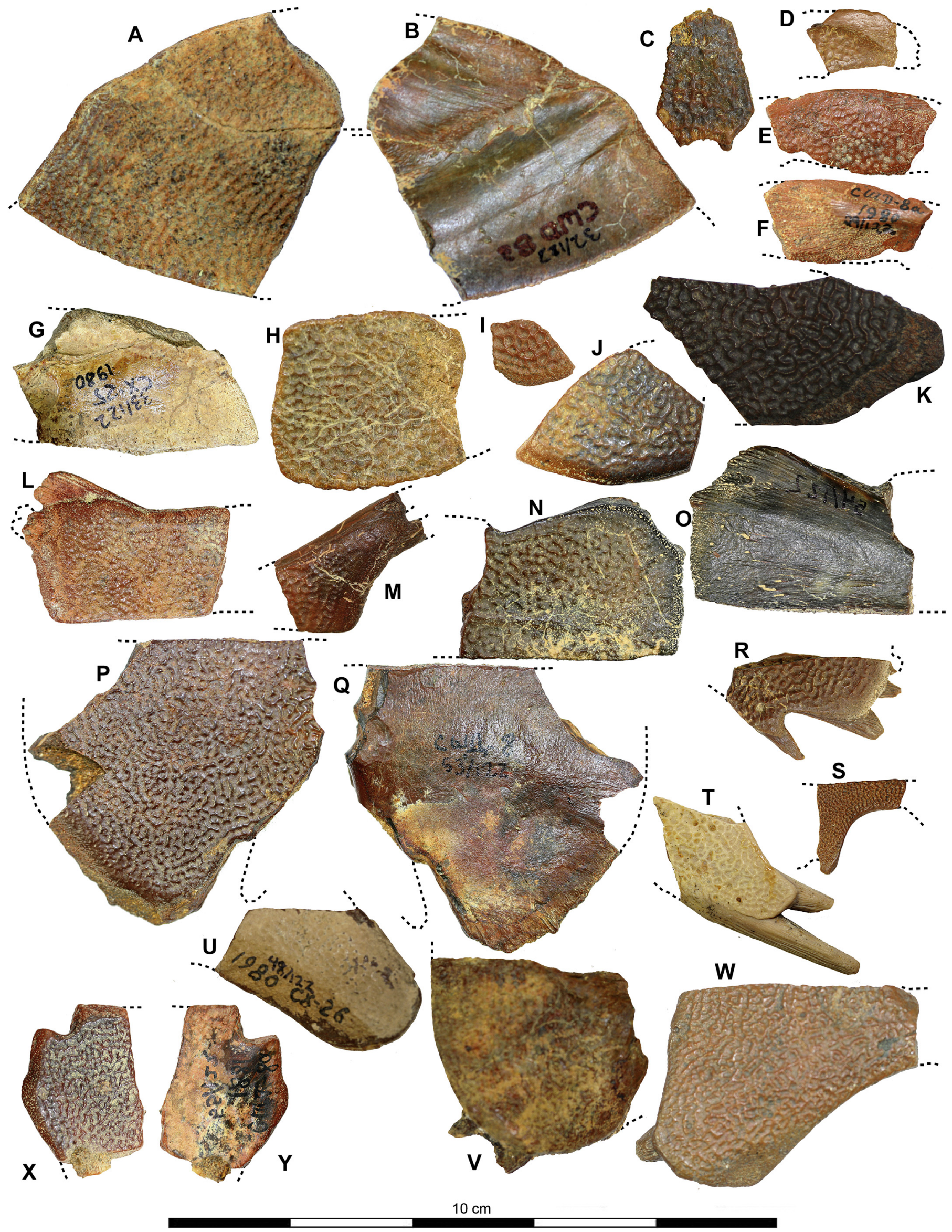




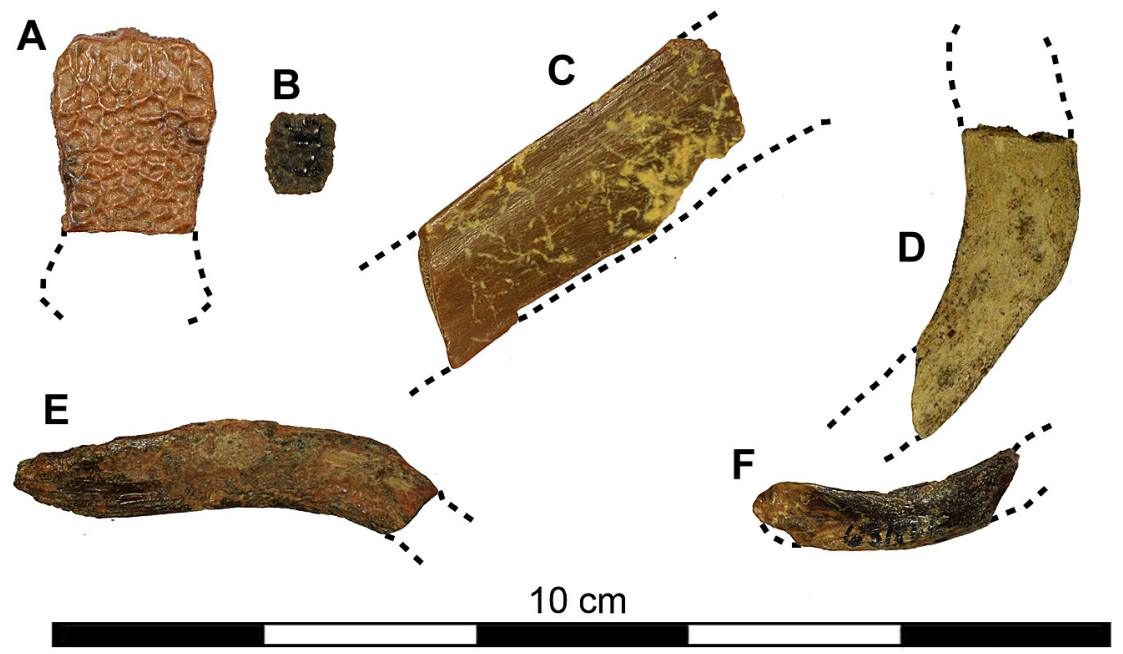

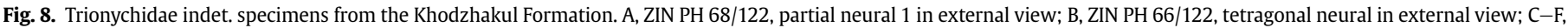
partial entoplastra or epiplastra? in external or visceral views: C, ZIN PH 60/122; D, ZIN PH 61/122; E, ZIN PH 62/122; F, ZIN PH 63/122.

Hyoplastra and hypoplastra. The hyoplastra and hypoplastra are not fused together. The plastral bridge is approximately one-third the width of the hypoplastron (Fig. 2F, G).

A smaller medial hyoplastron fragment (ZIN PH 46/122; Fig. 7L) has multiple small processes. They are broken and an exact count is impossible. The callosity does not entirely cover these processes, and instead forms a relatively straight anterior margin, and therefore a hyoplastral lappet. In another, larger medial hyoplastron fragment (ZIN PH 54/122; Fig. 7N, O), the callosity has covered all but $1-2 \mathrm{~mm}$ of the medial processes. The callosity's medial margin indicates that it contacted the other hyoplastron at the midline. In addition, the fragment shows the beginning of a shoulder, or an anterior flap and epiplastral notch like the kind seen in Plastomenidae. The lateral hyoplastral processes (ZIN PH 50/122; Fig. 7M) are angled and extend laterally past the hyo- hypoplastral suture.

The medial hypoplastral processes are divided into anteromedial and posteromedial groups (ZIN PH 53/122; Fig. 7P, Q). Smaller specimens (ZIN PH 52/122; Fig. 7R), are less extensively callosified and the processes are still exposed. Larger specimens (ZIN PH 53/ 122 ) have processes entirely covered by a callosity. The hypoplastral bridge (ZIN PH 57/122; Fig. 7S) has a relatively broad curve that is more similar to the hypoplastral bridge of most trionychines than to that of Paleogene plastomenids or other well-ossified trionychids. The two lateral hypoplastral processes are left exposed on some specimens (ZIN PH 51/122; Fig. 7T), but in others are covered by large, rounded callosities, that extend to form a nearly perpendicular margin with the hyo-hyoplastral suture in some specimens (ZIN PH 48/122, ZIN PH 47/122, ZIN PH 49/122, Fig 7U-W).

Xiphiplastron. ZIN PH 55/122 (Fig. 7X, Y) probably represents the anterolateral part of the xiphiplastron. The preserved part is completely covered by a callosity.

Trionychidae indet.

Referred material. ZIN PH 68/122 (SSHD-8), partial neural 1; ZIN PH 66/122 (?), tetragonal neural; ZIN PH 60/122 (SCH-“V”), ZIN PH 61/
122 (SKH-25), ZIN PH 62/122 (?), ZIN PH 63/122 (?), partial entoplastra or epiplastra?.

Locality, Horizon, and Age (referred material). Chelpyk and Sheikhdzheili localities, southwestern Kizylkum Desert area, Karakalpakistan, Uzbekistan; Khodzhakul Formation, early Cenomanian.

Description. One anterior neural 1 fragment (ZIN PH 68/122; Fig. 8A) and a small tetragonal neural (ZIN PH 66/122; Fig. 8B), have sculpturing that could conceivably belong to either species present in the Khodzhakul Formation.

Among the collected material there are several long, thin, uncallosified specimens (ZIN PH 60/122, ZIN PH 61/122, ZIN PH 62/ 122, ZIN PH 63/122; Fig. 8C-F) that do not resemble free ends of ribs. They are interpreted as entoplastron or epiplastron fragments. One fragment (ZIN PH 60/122) is wide and flattened, similar to the entoplastron of "Trionyx" kyrgyzensis, and another (ZIN PH 61/122) most resembles the medial epiplastron of "T." kyrgyzensis.

\section{Discussion}

The examined shell material of trionychids from Itemir and the Khodzhakul Formation is assigned to "Trionyx" cf. kyrgyzensis, "T." dissolutus sp. nov. and Trionychidae indet. The material referred to Trionychidae indet. may belong to one of the two described trionychid taxa.

"Trionyx" cf. kyrgyzensis is assigned to Trionychinae based on the combination of the following characters: the nuchal is at least three times wider than long, the neural series contains at least one reversal in neural orientation (synapomorphies of Trionychinae sensu Meylan, 1987), and eight neurals are present (as compared to Plastomenidae which have seven neurals; Joyce and Lyson, 2011). "Trionyx" cf. kyrgyzensis is very similar to "T." kyrgyzensis in the general morphology of the shell elements and sculpture pattern, but differs from it in size and greater degree of ossification in the

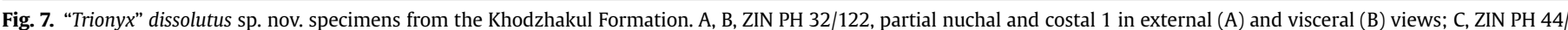

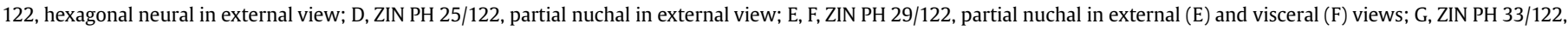

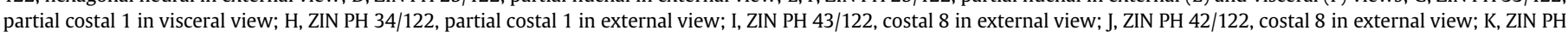

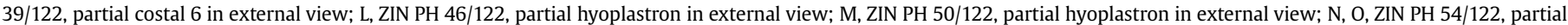

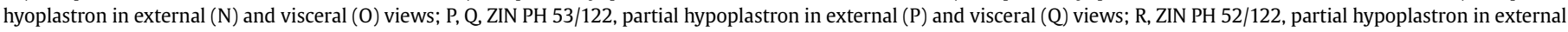

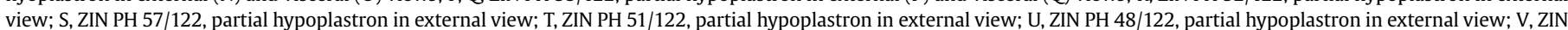

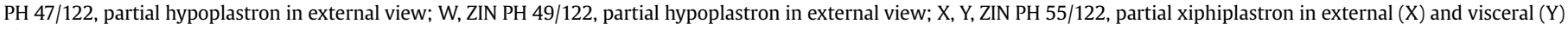
views. 
shell. It is unclear if these differences are ontogenetic or specific. Nessov (1995) considered "T." kyrgyzensis material to be from adult specimens, based on the fact that other fossil turtle material in the locality came from adult specimens. Nessov's (1995) reconstruction of "T." kyrgyzensis did not show postnuchal fontanelles, but an examination of the holotype material shows that the posteromedial margin of the nuchal, the medial margin of costal 1 , neural 1 , and a possible preneural are not preserved, so whether or not "T." kyrgyzensis had postnuchal fontanelles is unclear. Nessov (1995) tentatively reconstructed "T." kyrgyzensis with a preneural, but as is the case with postnuchal fontanelles, there is no clear evidence for this decision. Long free rib ends of "T." kyrgyzensis may represent an ontogenetic character. To clarify these questions, new material of "T." kyrgyzensis is needed.

"Trionyx" dissolutus demonstrates characters of both Trionychinae and Plastomenidae. The trionychine characters of " $T$." dissolutus include a nuchal that is at least three times wider than long, and a neural series that contains at least one reversal in neural orientation. Moreover, previously, the holotype specimen of "T." dissolutus was assigned to Trionychini Gray, 1825 as Trionychini indet. 1 based on the presence of seven or fewer neurals (Danilov and Vitek, 2012). It is important to note that although Meylan's (1987) cladistic analysis recovered a monophyletic Trionychini, subsequent phylogenetic analyses have not (Engstrom et al., 2004; Joyce and Lyson, 2010).

The extensive callosities, especially the anterior hyoplastral flap, seen in "Trionyx" dissolutus are reminiscent of the plastron of Plastomenidae, an extinct clade of trionychids from the Cretaceous Paleogene of North America (Hutchison, 2009; Joyce et al., 2009; Joyce and Lyson, 2010, 2011). Characters diagnosing Plastomenidae and uniting them with Cyclanorbinae Hummel, 1929 have recently been revised (Joyce et al., 2009; Joyce and Lyson 2010, 2011). Among the symplesiomorphies between plastomenids and cyclanorbines are the fusion of the hyo- and hypoplastron, the absence of postnuchal fontanelles, and the presence of a depression for contact with the ilia on costals 8 . None of these characters are present in "T." dissolutus. Other characters, such as the presence of a preneural and seven callosities on the plastron, are unknown for " $T$." dissolutus.

Three of the four characters that unite Plastomenidae and Cyclanorbinae are skull characters, which are not currently useful for "Trionyx" dissolutus. The fourth, the hypo-xiphiplastral contact with the hypoplastron lateral to the xiphiplastron, is not present in "T." dissolutus.

Of the six synapomorphies that unite Plastomenidae, only three are shell characters: the nuchal is at least four times wider than long, seven neurals in addition to the preneural and xiphiplastra contact one another along their entire length (Joyce and Lyson, 2011). Of these characters, "T." dissolutus demonstrates only similar proportions of the nuchal, which alone is not diagnostic because it is also present in members of Trionychinae. In contrast to Plastomenidae, "T." dissolutus has only six neurals. Hutchison's (2009) diagnosis of Plastomeninae includes two characters: the posterolateral arm of the epiplastron reduced or absent, and hyohypo-xiphiplastra that lack fontanelles and have patent sutures in adults. These characters are either unknown or not present in "T." dissolutus.

The combination of characters seen in "Trionyx" dissolutus indicates that it is not a plastomenid, despite having some superficial resemblance. For this reason and because "T." dissolutus shares trionychine synapomorphies we place it in Trionychinae incertae sedis. "Trionyx" dissolutus demonstrates that a heavily ossified plastron may be more homoplastic within Trionychidae than has been previously recognized.

The conclusion that "Trionyx" dissolutus is not a plastomenid is in agreement with our previous statement that, at present, no diagnosable specimens of Plastomenidae are known from the Cretaceous of Asia (Danilov and Vitek, 2012). On the other hand, new data on Cretaceous trionychids of Asia suggest that most supra-generic clades of modern trionychids (including the cyclanorbine-plastomenid clade) had already evolved in Asia by the Late Cretaceous and should be present in the fossil record (Danilov et al., in press).

Thus, our study demonstrates the presence of two shell-based trionychid taxa in Itemir and in localities of the Khodzhakul Formation. Previously, one or two trionychid taxa were reported from these localities (see Nessov, 1997): Palaeotrionyx sp. and Trionychinae indet. (Chelpyk, Khodzhakulsai, Sheikhdzheili); Trionychidae indet. (Khodzhakul I and II); Trionychidae indet. or Trionychinae indet. (Itemir). Our determinations are different: "Trionyx" cf. kyrgyzensis and "T." dissolutus. "Trionyx" cf. kyrgyzensis is larger than "T." kyrgyzensis, the only trionychid taxon from the older (early-middle Albian) Alamyshik Formation of Kylodzhun (Kyrgyzstan). Both "T." cf. kyrgyzensis and "T." dissolutus are smaller than trionychids (Aspideretoides cf. riabinini and "Trionyx" cf. kansaiensis) from younger (late Turonian) Bissekty Formation of Dzharakuduk (Uzbekistan), which are in turn smaller than trionychids (A. riabinini and "T." kansaiensis) from the early Santonian Yalovach Formation of Kansai (Tadzhikistan) and Santonian - early Campanian Bostobe Formation of Shakh Shakh (Kazakhstan) (Vitek and Danilov, 2010; Danilov and Vitek, 2013). It is interesting that patterns of the shell sculpturing of "T." cf. kyrgyzensis and "T." dissolutus are similar to those of $A$. riabinini and "T." kansaiensis respectively. In addition, "T." dissolutus is similar to "T." cf. kansaiensis and Trionychidae indet. specimens from Dzharakuduk in degree of ossification and configuration of plastral bones. These similarities may indicate close relationships between "T." dissolutus and "T." cf. kansaiensis.

Our results improve our understanding of the taxa of Trionychidae within assemblages of the Khodzhakul Formation and Itemir as well as similarities and differences between Cretaceous turtle assemblages of Middle Asia and Kazakhstan in general. In addition to the same trionychid species, turtle assemblages of the Khodzhakul Formation and Itemir share the presence of the same families, genera and species, which are Adocus Cope, 1868 (Adocidae Cope, 1870), "Ferganemys" itemirensis Nessov, 1981 (Adocidae), Kizylkumemys schultzi Nessov, 1976 (Carettochelyidae Boulenger, 1887), and Anatolemys oxensis Nessov et Khosatzky in Nessov, 1977a (Macrobaenidae Sukhanov, 1964). The differences between these turtle assemblages are the following (Table 2): 1) potentially different species of Adocus (Adocus sp. in Itemir and Adocus kizylkumensis in the Khodzhakul Formation (Syromyatnikova and Danilov, 2009); 2) the presence of Khodzhakulemys occidentalis (Nessov in Nessov and Krasovskaya, 1984) (Lindholmemydidae Chkhikvadze in Shuvalov and Chkhikvadze, 1975) in the Khodzhakul Formation (Nessov and Krasovskaya, 1984; Danilov, 1999); 3) the presence of a second macrobaenid in the Khodzhakul Formation (Macrobaenidae indet.; = Kirgizemys sp.; = Kirgizemys(?) sp.; = cf. Kirgizemys sp.; Nessov, 1997); 4) the presence of Nanhsiungchelyidae indet. in the Khodzhakul Formation (Danilov and Syromyatnikova, 2008); 5) the presence of a problematic shellbased taxon Parathalassemys cava Nessov in Nessov and Krasovskaya, 1984 in Itemir (Nessov and Krasovskaya, 1984); 6) the presence of a problematic shell-based taxon Tienfucheloides undatus Nessov, 1978 in the Khodzhakul Formation (Nessov, 1978); 7) the presence of a problematic skull-based taxon Oxemys gutta Nessov, 1977b in the Khodzhakul Formation (Nessov, 1977b). Most probably, these differences are explained by a lack of knowledge concerning the turtle assemblages of the Khodzhakul Formation and Itemir and the fragmentary nature of the material. Both of these Cenomanian turtle assemblages have similarities with the 
Table 2

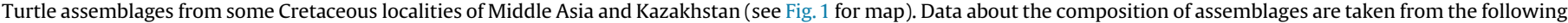
publications: Nessov (1997); Vitek and Danilov (2010); Danilov et al. (2011); Danilov and Vitek (2012); Vitek and Danilov (2012). See text for other details.

\begin{tabular}{|c|c|c|c|c|c|c|}
\hline $\begin{array}{l}\text { Baybishe and Shakh Shakh } \\
\text { (Bostobe Fm., Santonian - } \\
\text { early Campanian) }\end{array}$ & $\begin{array}{l}\text { Dzharakuduk } \\
\text { (Bissekty Fm., late } \\
\text { Turonian) }\end{array}$ & $\begin{array}{l}\text { Itemir } \\
\text { (Cenomanian) }\end{array}$ & $\begin{array}{l}\text { Kansai (Yalovach } \\
\text { Fm., early } \\
\text { Santonian) }\end{array}$ & $\begin{array}{l}\text { Localities of the } \\
\text { Khodzhakul Fm. } \\
\text { (early Cenomanian) }\end{array}$ & $\begin{array}{l}\text { Kylodzhun } \\
\text { (Alamyshik } \\
\text { Fm., early- } \\
\text { middle Albian }\end{array}$ & $\begin{array}{l}\text { Kyrkkuduk I (Syuk } \\
\text { Syuk Fm. \& ?Darbaza } \\
\text { Fm., Santonian - ? } \\
\text { middle Campanian) }\end{array}$ \\
\hline \multicolumn{7}{|l|}{ Adocidae } \\
\hline Adocus bostobensis & Adocus aksary & Adocus sp. & Adocus foveatus & Adocus kizylkumensis & & - \\
\hline Shachemys baibolatica & $\begin{array}{l}\text { Shachemys } \\
\text { ancestralis }\end{array}$ & $\begin{array}{l}\text { "Ferganemys" } \\
\text { itemirensis }\end{array}$ & $\begin{array}{l}\text { Shachemys } \\
\text { baibolatica }\end{array}$ & “Ferganemys" itemirensis & $\begin{array}{l}\text { Ferganemys } \\
\text { verzilini }\end{array}$ & Shachemys sp. \\
\hline \multicolumn{7}{|l|}{ Carettochelyidae } \\
\hline- & - & $\begin{array}{l}\text { Kizylkumemys } \\
\text { schultzi }\end{array}$ & - & Kizylkumemys schultzi & - & - \\
\hline \multicolumn{7}{|l|}{ Lindholmemydidae } \\
\hline Lindholmemys sp. cf. L. gravis & Lindholmemys elegans & - & $\begin{array}{l}\text { Lindholmemys } \\
\text { gravis }\end{array}$ & Khodzhakulemys occidentalis & & Lindholmemys sp. \\
\hline \multicolumn{7}{|l|}{ Macrobaenidae } \\
\hline Anatolemys maximus & $\begin{array}{l}\text { Anatolemys sp. cf. } \\
\text { maximus }\end{array}$ & $\begin{array}{l}\text { Anatolemys } \\
\text { oxensis }\end{array}$ & $\begin{array}{l}\text { Anatolemys } \\
\text { maximus }\end{array}$ & Anatolemys oxensis & $\begin{array}{l}\text { Kirgizemys } \\
\text { exaratus }\end{array}$ & - \\
\hline- & Macrobaenidae indet. & - & - & Macrobaenidae indet. & - & - \\
\hline \multicolumn{7}{|l|}{ Nanhsiungchelyidae } \\
\hline \multicolumn{7}{|c|}{ Trionychidae (shell-based taxa) } \\
\hline Aspideretoides riabinini & $\begin{array}{l}\text { Aspideretoides } \\
\text { cf. riabinini }\end{array}$ & $\begin{array}{l}\text { "Trionyx" } \\
\text { cf. kyrgyzensis }\end{array}$ & $\begin{array}{l}\text { Aspideretoides } \\
\text { riabinini }\end{array}$ & "Trionyx" cf. kyrgyzensis & $\begin{array}{l}\text { "Trionyx" } \\
\text { kyrgyzensis }\end{array}$ & - \\
\hline “Trionyx" kansaiensis & $\begin{array}{l}\text { "Trionyx" } \\
\text { cf. kansaiensis }\end{array}$ & $\begin{array}{l}\text { "Trionyx" } \\
\text { dissolutus }\end{array}$ & $\begin{array}{l}\text { "Trionyx" } \\
\text { kansaiensis }\end{array}$ & "Trionyx" dissolutus & - & "Trionyx" kansaiensis \\
\hline “Paleotrionyx" riabinini & - & - & - & - & - & - \\
\hline- & Trionychidae indet. & - & - & - & - & Trionychidae indet. \\
\hline \multicolumn{7}{|c|}{ Trionychidae (skull-based taxa) } \\
\hline Khunnuchelys sp. 1 & $\begin{array}{l}\text { Khunnuchelys } \\
\text { kizylkumensis }\end{array}$ & - & - & - & - & - \\
\hline- & Trionychini indet. & - & - & - & - & - \\
\hline- & - & - & $\begin{array}{l}\text { Trionychidae } \\
\text { indet. } 4\end{array}$ & - & - & - \\
\hline \multicolumn{7}{|l|}{ Testudines incertae sedis } \\
\hline- & - & - & - & Oxemys gutta & - & - \\
\hline- & - & $\begin{array}{l}\text { Parathalassemys } \\
\text { cava }\end{array}$ & - & - & - & - \\
\hline- & - & - & - & Tienfucheloides undatus & - & - \\
\hline- & - & Testudines indet. & - & Testudines indet. & - & - \\
\hline
\end{tabular}

older (early-middle Albian) turtle assemblage of Kylodzhun (see above) in the presence of Ferganemys Nessov and Khosatzky, 1977 (Adocidae), Macrobaenidae and "Trionyx" (Trionychidae). The differences between these assemblages are different genera and species within mentioned families and genera (see Table 2). On the other hand, the Cenomanian turtle assemblages have similarities with the younger (late Turonian) turtle assemblage of Dzharakuduk in the presence of Adocus (Adocidae), the second adocid ("Ferganemys" itemirensis in the Khodzhakul Formation and Itemir and Shachemys ancestralis Nessov in Nessov and Krasovskaya, 1984 in Dzharakuduk which are closely related; Syromyatnikova, 2011), Lindholmemydidae, Anatolemys (Macrobaenidae), the second macrobaenid (Macrobaenidae indet.) and "Trionyx" (Trionychidae). The differences between these assemblages are different genera and species within mentioned families and genera, the absence of Carettochelyidae, Nanhsiungchelyidae and the above-mentioned problematic taxa in Dzharakuduk, and the presence of Aspideretoides cf. riabinini in Dzharakuduk. These differences reflect a large change in the turtle assemblages composition, which took place in Middle Asia in the early Turonian, when small, thin-shelled turtles were replaced with large and thick-shelled ones (Nessov, 1985, 1997). These changes are thought to have been caused by a large early Turonian transgression as well as by the appearance of a large turtle-eating crocodile (Shamosuchus) and large predatory fishes (Ichthyodectidae) (Nessov, 1985).

The similarities between the turtle assemblages of the Khodzhakul Formation and Itemir, on the one hand, and between these Cenomanian assemblages and turtle assemblage of Dzharakuduk, on the other hand, are not surprising in view of their geographic proximity and similar ages and are in close agreement with data on other vertebrates (Averianov and Sues, 2012).

\section{Acknowledgments}

Thanks to two anonymous reviewers whose comments improved the manuscript. Fieldwork for this study was funded by grants from the National Science Foundation (EAR-9804771 and 0207004) and National Geographic Society (5901-97 and 6281-98) to J. D. Archibald and H.-D. Sues, and US Civilian Research and Development Foundation grant RUB1-2860-ST-07 to Alexander Averianov and J. D. Archibald. We thank all members of the URBAC expedition for their help during fieldwork. Laboratory work for this study was funded by a grant from the President of the Russian Federation to the Leading Scientific Schools NSh-2990.2014.4 and a grant of the Russian Foundation for Basic Research No. 14-04-00416 to I.G.D and by a Robert C. Bates Travelling Fellowship to N.S.V.

\section{References}

Averianov, A.O., Archibald, J.D., 2005. Mammals from the mid-Cretaceous Khodzhakul Formation, Kizylkum Desert, Uzbekistan. Cretaceous Research 26, 593608.

Averianov, A.O., Sues, H.-D., 2007. A new troodontid (Dinosauria: Theropoda) from the Cenomanian of Uzbekistan, with a review of troodontid records from the territories of the former Soviet Union. Journal of Vertebrate Paleontology 27 (1), 87-98.

Averianov, A., Sues, H.-D., 2012. Correlation of Late Cretaceous continental vertebrate assemblages in Middle and Central Asia. Journal of Stratigraphy 36, 1-25. 
Batsch, A.J.G.C., 1788. Versuch einer Anleitung, zur Kenntnis und Geschichte der Thiere und Mineralien. Akademische Buchhandlung, Jena, 528 p.

Boulenger, G.A., 1887. On a new family of pleurodiran turtles. Annals and Magazine of Natural History 19, 170-172.

Cope, E.D., 1868. On the origin of genera. Proceedings of the Academy of Natural Sciences of Philadelphia 1868, 242-300.

Cope, E.D., 1870. On the Adocidae. Proceedings of the American Philosophical Society $11,547-553$.

Danilov, I.G., 1999. A new lindholmemydid genus (Testudines: Lindholmemydidae) from the mid-Cretaceous of Uzbekistan. Russian Journal of Herpetology 6 (1), $63-71$.

Danilov, I.G., Hirayama, R., Sukhanov, V.B., Suzuki, S., Watabe, M., Vitek, N.S., 2014. Cretaceous soft-shelled turtles (Trionychidae) of Mongolia: new diversity, records, and a revision. Journal of Systematic Palaeontology in press.

Danilov, I.G., Syromyatnikova, E.V., 2008. New materials on turtles of the family Nanhsiungchelyidae from the Cretaceous of Uzbekistan and Mongolia, with a review of the nanhsiungchelyid record in Asia. Proceedings of the Zoological Institute of the Russian Academy of Sciences 312 (1/2), 3-25.

Danilov, I.G., Vitek, N.S., 2009. Cretaceous trionychids of Asia: a review of record and biogeography. In: Gaffney Turtle Symposium (17-18 October 2009, Drumheller, Canada). Drumheller, Canada, pp. 52-58.

Danilov, I.G., Sukhanov, V.B., Syromyatnikova, E.V., 2011. New Asiatic materials on turtles of the family Adocidae with a review of the adocid record in Asia. Proceedings of the Zoological Institute of the Russian Academy Sciences 315 (2), $101-132$.

Danilov, I.G., Vitek, N.S., 2012. Chapter 23. Cretaceous trionychids of Asia: an expanded review of their record and biogeography. In: Brinkman, D.B., Holroyd, P.A., Gardner, J.D. (Eds.), Morphology and Evolution of Turtles. Springer, Berlin, pp. 419-438.

Danilov, I.G., Vitek, N.S., 2013. Soft-shelled turtles (Trionychidae) from the Bissekty Formation (Late Cretaceous: late Turonian) of Uzbekistan: Shell-based taxa. Cretaceous Research 41, 55-64.

Engstrom, T.N., Shaffer, H.B., McCord, W.P., 2004. Multiple data sets, high homoplasy, and the phylogeny of softshell turtles (Testudines: Trionychidae). Systematic Biology 53, 693-710.

Gardner, J.D., Russell, A.P., 1994. Carapacial variation among soft-shelled turtles (Testudines: Trionychidae), and its relevance to taxonomic and systematic studies of fossil taxa. Neues Jarbuch für Geologie und Paläeontologie 193, 209-244.

Gardner, J.D., Russell, A.P., Brinkman, D.B., 1995. Systematics and taxonomy of softshelled turtles (Family Trionychidae) from the Judith River Group (mid-Campanian) of North America. Canadian Journal of Earth Sciences 32, 631-643.

Gilmore, C.W. 1928. Description of two new species of fossil turtles, from the Lance Formation of Wyoming. Proceedings of the US National Museum 50, 641-646.

Gray, J.E., 1825. A synopsis of the genera of reptiles and amphibia, with a description of some new species. Annals of Philosophy 10, 193-217.

Hay, O.P., 1902. Bibliography and Catalogue of the Fossil Vertebrata of North America. Government Printing Office, Washington, DC, 868 pp. (Bulletin of the United States Geological Survey 179).

Hummel, K., 1929. Die fossilen Weichschildkroten (Trionychia). Eine morphologischsystematische und stammesgeschichtliche studie. Geologische und Palaeontologische, Abhandlungen 16, 359-487.

Hutchison, J.H., 2009. New soft-shelled turtles (Plastomeninae: Trionychidae: Testudines) from the Late Cretaceous and Paleocene of North America. Paleobios $29,36-47$.

Joyce, W.G., Lyson, T.R., 2010. A neglected lineage of North America turtles fills a major gap in the fossil record. Palaeontology 53, 241-248.

Joyce, W.G., Lyson, T.R., 2011. New material of Gilmoremys lancensis nov. comb. (Testudines: Trionychidae) from the Hell Creek Formation and the diagnosis of plastomenid turtles. Journal of Paleontology 85, 442-459.

Joyce, W.G., Revan, A., Lyson, T.R., Danilov, I.G., 2009. Two new plastomenine softshell turtles from the Paleocene of Montana and Wyoming. Bulletin of the Peabody Museum of Natural History 50, 307-325.

Karl, H.-V.. 1998. Zur Taxonomie der känozoischen Weichschildkröten Österreichs und Deutschlands (Trionychidae: Trionychinae). Mitteilungen der Abteilungs für Geologie und Paläontologie der Landesmuseum Joanneum 56, 273-328.
Karl, H.-V., 1999. Die Zoogeographie der känozoischen Weichschildkröte Trionyx triunguis Forskäl, 1775. Joannea Geologie und Paläontologie 1, 27-60.

Kordikova, E.G., 1992. Review of fossil trionychid turtles of the USSR. Izvestiya Akademii Nauk Gruzii 18, 131-141 (in Russian).

Kordikova, E.G., 1994. Review of fossil trionychid localities in the Soviet Union. Courier Forschungs-Institut Senckenberg 173, 341-358.

Kuznetsov, V.V., Chkhikvadze, V.M., 1987. The Late Cretaceous trionychids from the Shakh-Shakh locality in Kazakhstan. Materialy po istorii fauny i flory Kazakhstana 9, 33-39 (in Russian).

Meylan, P.A., 1987. The phylogenetic relationships of soft shelled turtles (family Trionychidae). Bulletin of the American Museum of Natural History 186, 1-101.

Nessov, L.A., 1976. On the systematics and phylogeny of two-clawed turtles. Vestnik Leningradskogo Gosudarstvennogo Universiteta 9, 85-93 (in Russian).

Nessov, L.A., 1977a. Turtles and some other reptiles of the Cretaceous of Karakalpakia. In: Voprosy Herpetologii. Nauka, Leningrad, pp. 155-156 (in Russian).

Nessov, L.A., 1977b. About some peculiarities of skull of two Late Cretaceous turtles Vestnik Leningradskogo Gosudarstvennogo Universiteta 21, 45-48 (in Russian).

Nessov, L.A., 1978. An archaic Late Cretaceous turtle from western Uzbekistan Paleontologicheskii Zhurnal 4,101-105 (in Russian).

Nessov, L.A., 1981. On the turtle of the family Dermatemydidae from the Cretaceous of Amur River Basin and some other rare findings of remains of ancient turtles of Asia. In: Borkin, L.Ya. (Ed.), Herpetological Investigations in Siberia and the Far East. Zoological Institute, Academy of Sciences of the USSR, Leningrad, pp. 69-73 (in Russian).

Nessov, L.A., Khosatzky, L.I., 1977. Freshwater turtle from the Early Cretaceous of Fergana, Ezhegodnik Vsesoyuznogo Paleontologicheskogo Obshchestva 20, 248-262 (in Russian).

Nessov, L.A., 1984. Preservation of remains of organisms and conditions of their burial in Kulbike Member of Itemir. In: Ochev, V.G. (Ed.), Tafonomiya i Voprosy Paleogeografii. Saratov University, Saratov, pp. 62-76 (in Russian).

Nessov, L.A., 1985. Data on Late Mesozoic turtles from the USSR. Studia Palaeocheloniologica 1, 215-223.

Nessov, L.A., 1986. Some Late Mesozoic and Paleocene turtles of Soviet Middle Asia. Studia Palaeocheloniologica 2, 7-22.

Nessov, L.A., 1995. On some Mesozoic turtles of the Fergana Depression (Kyrgyzstan) and Dzhungar Alatau Ridge (Kazakhstan). Russian Journal of Herpetology 2, 134-141.

Nessov, L.A., 1997. Nemorskie pozvonochnye melovogo perioda Severnoy Evrazii (Cretaceous nonmarine vertebrates of Northern Eurasia). Saint Petersburg State University, Institute of Earth Crust, Saint Petersburg (in Russian).

Nessov, L.A., Krasovskaya, T.B., 1984. Changes in the composition of turtles assemblages of Late Cretaceous of Middle Asia. Vestnik Leningradskogo Gosudarstvennogo Universiteta 3, 15-25 (in Russian).

Shuvalov, V.F., Chkhikvadze, V.M., 1975. New data on Late Cretaceous turtles of South Mongolia. Trudy Sovmestnoy Sovetsko-Mongol'skoy Paleontologicheskoy Ekspeditsii 2, 214-229 (in Russian).

Sukhanov, V.B., 1964. Podklass Testudinata (Subclass Testudinata.). In: Rozhdestvensky, A.K., Tatarinov, L.P. (Eds.), Osnovy paleontologii. Zemnovodnye, Presmykayushchiesya I Ptitsy. Nauka, Moskva, pp. 354-438 (in Russian).

Syromyatnikova, E.V., 2011. Turtles of the genus Ferganemys Nessov et Khosatzky, 1977 (Adocidae): shell morphology and phylogenetic position. Proceedings of the Zoological Institute of the Russian Academy of Sciences 315 (1), 38-52.

Syromyatnikova, E.V., Danilov, I.G., 2009. New material and a revision of turtles of the genus Adocus (Adocidae) from the Late Cretaceous of Middle Asia and Kazakhstan. Proceedings of the Zoological Institute of the Russian Academy of Sciences 313 (1), 74-94.

Vitek, N.S., Danilov, I.G., 2010. New material and a reassessment of soft-shelled turtles (Trionychidae) from the Late Cretaceous of Middle Asia and Kazakhstan. Journal of Vertebrate Paleontology 30, 383-393.

Vitek, N.S., Danilov, I.G., 2012. New data on the soft-shelled turtles from the Uppe Cretaceous Kyrkkuduk I locality of Southern Kazakhstan. Proceedings of the Zoological Institute RAS 316, 50-56.

Vitek, N.S., Danilov, I.G., 2013. Soft-shelled turtles (Trionychidae) from the Bissekty Formation (Upper Cretaceous: Turonian) of Uzbekistan: Skull-based taxa and probable skull-shell associations. Cretaceous Research 43, 48-58. 